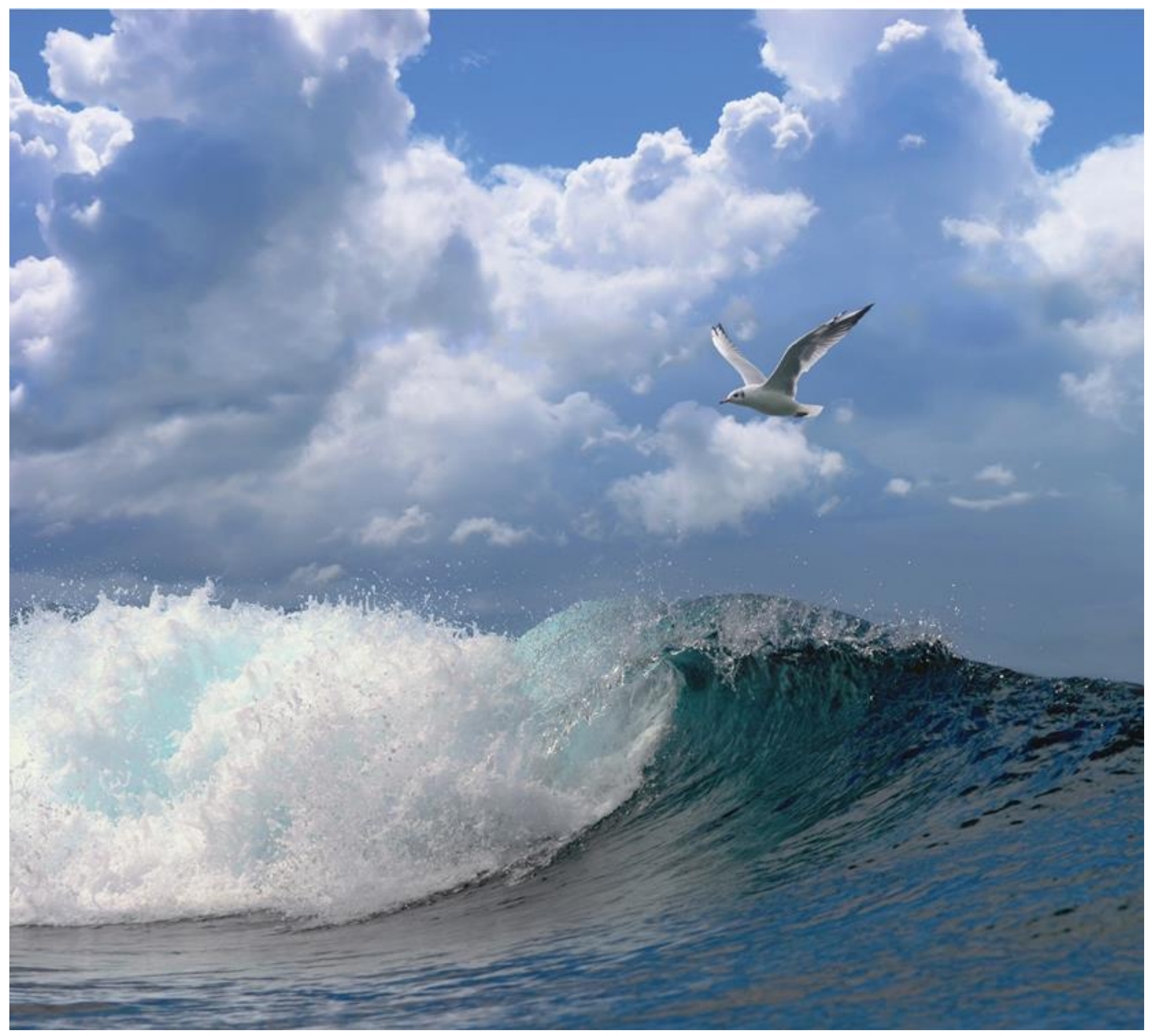

\title{
Toxicity of DMSO extracts tested with 4 freshwater bioassays
}

Test report 


\section{Toxicity of DMSO extracts tested with 4 freshwater bioassays}

Test report

Author(s): $\quad$ M.C. Keur 
Keywords: toxicity tests, extracts, fresh water, ecotoxicity, acute, chronic

Client: $\quad$ WEnR (Wageningen Environmental Research)

Paul van den Brink, Lara Schuijt

This report can be downloaded for free from https://doi.org/10.18174/509861

Wageningen Marine Research provides no printed copies of reports

Wageningen Marine Research is ISO 9001:2015 certified.

(C) Wageningen Marine Research

Wageningen Marine Research, an institute Wageningen Marine Research accepts no liability for consequential damage, nor within the legal entity Stichting for damage resulting from applications of the results of work or other data Wageningen Research (a foundation under obtained from Wageningen Marine Research. Client indemnifies Wageningen Dutch private law) represented by $\mathrm{Dr}$. Marine Research from claims of third parties in connection with this application. M.C.Th. Scholten, Managing Director All rights reserved. No part of this publication may be reproduced and / or published, photocopied or used in any other way without the written permission

KvK nr. 09098104 of the publisher or author.

WMR BTW nr. NL 8113.83.696.B16.

Code BIC/SWIFT address: RABONL2U

IBAN code: NL 73 RABO 0373599285 


\section{Contents}

1 Introduction $\quad 4$

$2 \quad$ Materials and Methods $\quad 4$

2.1 Abbreviations 4

2.2 Test material $\quad 4$

2.3 Test method 4

$3 \quad$ Results $\quad 5$

4 Conclusion $\quad 6$

$5 \quad$ Quality Assurance $\quad 7$

$\begin{array}{lr}\text { Justification } & 8\end{array}$

$\begin{array}{llr}6 & \text { Annex } & 9\end{array}$

6.1 Freshwater acute luminescence inhibition test with the bacteria Vibrio fischeri 9

6.2 Freshwater algal growth inhibition test with Raphidocelis subcapitata 10

6.3 Freshwater acute immobility test with the crustacean Daphnia magna 11

6.4 Freshwater acute mortality test with the rotifer Brachionus calyciflorus 12 


\title{
1 Introduction
}

This report describes the results of toxicity tests performed on 30 DMSO extract samples with bacteria (Vibrio fischeri), algae (Raphidocelis subcapitata), crustacea (Daphnia magna) and rotifera (Brachionus calyciflorus).

Reported are the effects in luminescence inhibition (bacteria), growth inhibition (algae), immobilization inhibition (crustacea) and mortality (rotifera).

\section{$2 \quad$ Materials and Methods}

\author{
2.1 Abbreviations \\ AFW Artificial Fresh Water; EPA
}

\section{$2.2 \quad$ Test material}

Frozen samples were provided by the sponsor and were transported refrigerated from Wageningen University to Wageningen Marine Research $1^{\text {st }}$ November 2019. After arrival the samples were stored in $-20^{\circ} \mathrm{C}$ freezer until used in the experiment. The samples were gradually brought to room temperature before used in the experiment.

According to the sponsor each sample consisted of an extract in $100 \mu \mathrm{LMSO}$.

The samples were coded as nr. $1 \mathrm{t} / \mathrm{m} \mathrm{20,22,} \mathrm{23,} 24$ and $26 \mathrm{t} / \mathrm{m} 32$

A $2 \mathrm{ml} / \mathrm{I}$ DMSO solution was used as solvent control

\section{$2.3 \quad$ Test method}

The extract samples were transferred to $50 \mathrm{ml}$ tubes by rinsing the sample vials thoroughly with AFW to make sure all sample was collected. The tubes were then filled to $50 \mathrm{ml}$ with AFW, resulting in a final concentration of $100 \mu \mathrm{g}$ extract in $50 \mathrm{ml} \mathrm{AFW}(=2 \mathrm{ml} / \mathrm{L})$ that was tested.

After mixing $5 \mathrm{ml}$ subsamples of each sample were taken for chemical analysis and stored at $-20^{\circ} \mathrm{C}$. A solution of $2 \mathrm{ml} / \mathrm{I}$ DMSO was made as solvent control.

The test protocols of all 4 toxicity tests are described in annexes (Chapter 6) to this report. 


\section{Results}

All control parameters for the blank exposure in all toxicity tests complied with the requirements of the test protocols. Furthermore the sensitivity for the reference toxicant was according to the requirements of the test protocols and no observed toxicity was found in the solvent control.

In Table 1 and Figure 1 the combined toxicity data for all 4 toxicity tests is shown as percentages observed effect.

Table 1 Percentages of observed effect per sample for the 4 toxicity tests.

\begin{tabular}{|c|c|c|c|c|}
\hline Sample & Crustacea & Rotifera & Bacteria $^{1}$ & Algae \\
\hline & $\begin{array}{l}\text { \% immobile } \\
\text { individuals }\end{array}$ & $\begin{array}{l}\% \text { dead } \\
\text { individuals }\end{array}$ & $\begin{array}{l}\text { \% reduced } \\
\text { illumination } \\
\text { relative to } \\
\text { controls }\end{array}$ & $\begin{array}{l}\text { \% growth } \\
\text { inhibition relative } \\
\text { to controls }\end{array}$ \\
\hline Control & 5 & 3.3 & 0 & 0 \\
\hline Nr. 1 & 25 & 100 & 14 & 100 \\
\hline Nr. 2 & 0 & 0 & -26 & -1 \\
\hline Nr. 3 & 0 & 6.7 & -24 & -3 \\
\hline Nr. 4 & 0 & 3.3 & -19 & -1 \\
\hline Nr. 5 & 0 & 6.7 & -10 & -3 \\
\hline Nr. 6 & 5 & 0 & 25 & -5 \\
\hline Nr. 7 & 5 & 0 & -11 & -6 \\
\hline Nr. 8 & 5 & 3.3 & -5 & -9 \\
\hline Nr. 9 & 0 & 0 & 3 & 100 \\
\hline Nr. 10 & 5 & 0 & 3 & -6 \\
\hline Nr. 11 & 0 & 0 & 2 & -4 \\
\hline Nr. 12 & 0 & 0 & 13 & -4 \\
\hline Nr. 13 & 0 & 0 & 10 & 99 \\
\hline Nr. 14 & 5 & 0 & -2 & -1 \\
\hline Nr. 15 & 0 & 0 & -2 & -5 \\
\hline Nr. 16 & 5 & 0 & 7 & -4 \\
\hline Nr. 17 & 0 & 0 & 11 & -4 \\
\hline Nr. 18 & 40 & 100 & 24 & 100 \\
\hline Nr. 19 & 5 & 0 & 6 & 5 \\
\hline Nr. 20 & 0 & 0 & 7 & -1 \\
\hline Nr. 22 & 0 & 0 & 11 & -5 \\
\hline Nr. 23 & 0 & 0 & 3 & -7 \\
\hline Nr. 24 & 5 & 0 & 14 & -5 \\
\hline Nr. 26 & 0 & 0 & 16 & -6 \\
\hline Nr. 27 & 0 & 0 & -4 & 100 \\
\hline Nr. 28 & 0 & 0 & 6 & -1 \\
\hline Nr. 29 & 0 & 3.3 & 7 & -5 \\
\hline Nr. 30 & 0 & 0 & 7 & -5 \\
\hline Nr. 31 & 10 & 72.5 & 33 & 100 \\
\hline Nr. 32 & 0 & 0 & -3 & -1 \\
\hline $\begin{array}{l}\text { DMSO } \\
\text { control }\end{array}$ & 5 & 0 & -9 & 1 \\
\hline
\end{tabular}

${ }^{1}$ The bacteria data is a mean of 2 separately tested replicates 


\section{Combined data}

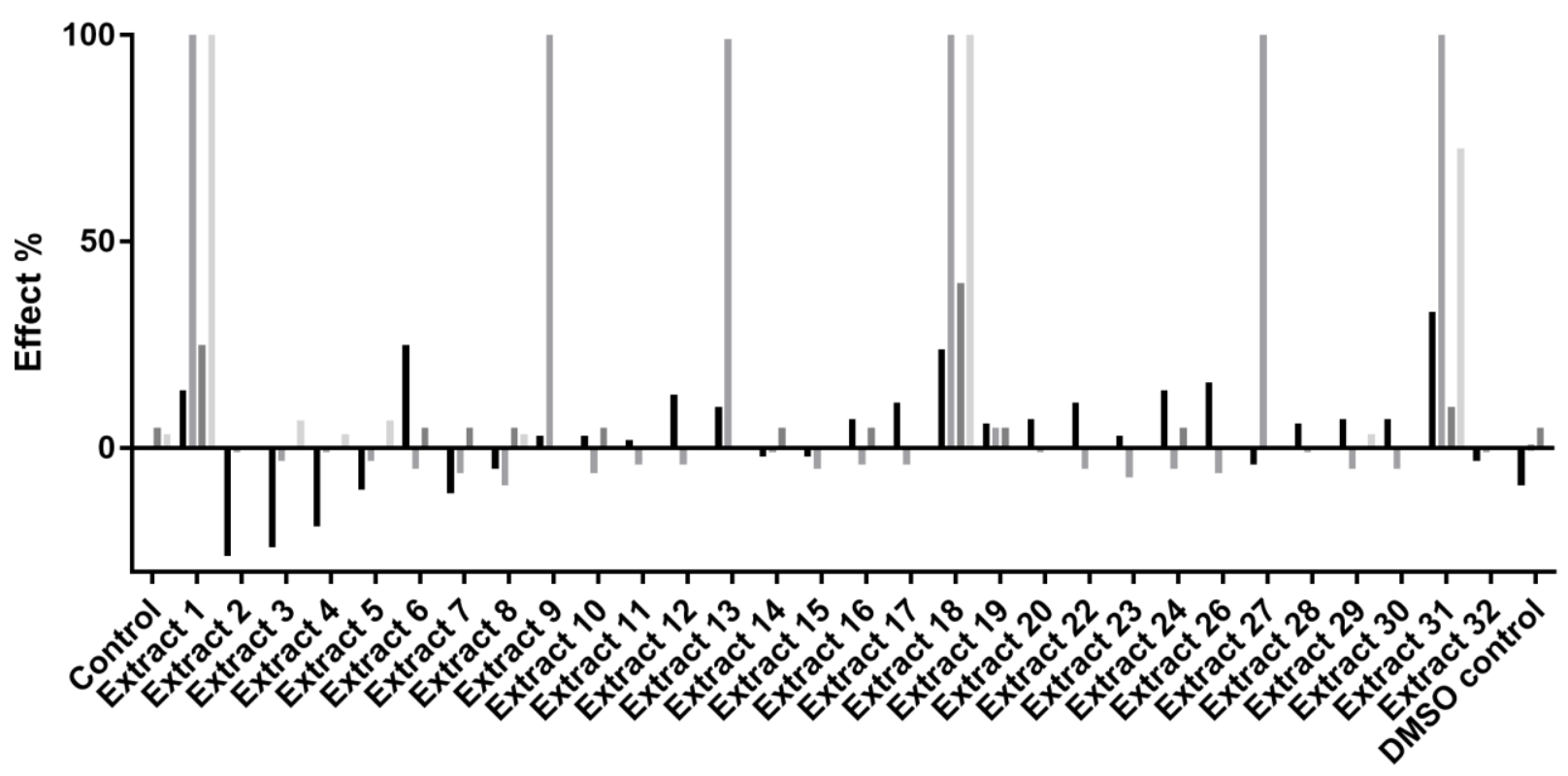

Sample

- Bacteria

Algae

Crustacea

Rotifera

Figure 1 Graph for the combined data of all 4 toxicity tests

\section{Conclusion}

Extracts nr. 1, 18 and 31 did show the highest effect, with heavy toxicity ( $\pm 100 \%$ effect) for both algae and rotifera and moderate toxicity for crustacea and bacteria.

Furthermore extract nr. 9, 13 and 27 did show heavy toxicity only for algae.

The other extracts and the solvent control with DMSO did not show significant effects for any of the toxicity tests performed. 


\section{Quality Assurance}

Wageningen Marine Research utilises an ISO 9001:2015 certified quality management system. This certificate is valid until 15 December 2021. The organisation has been certified since 27 February 2001. The certification was issued by DNV GL. 


\section{Justification}

Report C134/19

Project Number: 431.51001 .35

The scientific quality of this report has been peer reviewed by a colleague scientist and a member of the Management Team of Wageningen Marine Research

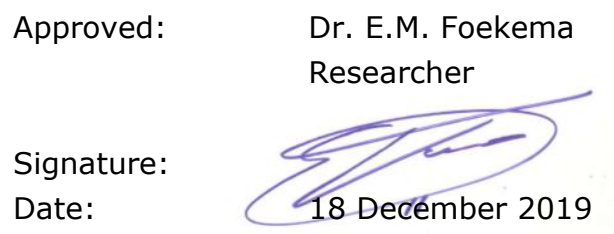

Approved: $\quad$ Drs. J. Asjes

Manager

Signature:

Date: 


\subsection{Freshwater acute luminescence inhibition test with the bacteria Vibrio fischeri}

This is a summary of the WMR SOP E_4_183 (in Dutch): 'Microtox Basic test met Vibrio fischeri'. This procedure follows the guidelines of ISO 11348-3:2007

\section{Description}

For the acute test with the bacteria Vibrio fischeri, freeze dried bacteria are used. The luminescence inhibition is determined by means of a batch test. The sample is diluted in a dilution series of 4 concentrations to which light emitting Vibrio fischeri are added. After addition of the bacteria the light emission of the test concentrations are measured after 5, 15 and 30 minutes. Luminescence inhibition is calculated by means of the Microtox Omni software. For each light measurement a correction factor is calculated. This factor are measurements of light intensity changes in control samples during exposure. After that the $\mathrm{EC}_{50}$, including standard deviations, of the luminescence inhibition percentages is calculated by means of the same software.

To achieve better results this test is performed in duplicate or triplicate.

\section{Quality assurance}

For each test series, the quality of the batch of the test organisms is determined by exposing organisms to a substance with a known toxicity (fenol). The results are compared results from previous reference tests with the same species at the WMR laboratory.

\section{Characteristics}

\begin{tabular}{|ll|}
\hline Inhibition test with Vibrio & WMR-SOP E_4_183 \\
fischeri & \\
Test organism & ISO-11348-3 (2007) \\
Salinity range & Vibrio fischeri \\
Test duration & $>10 \%$ \\
Test volume & 30 minutes \\
Number of replicates & $1 \mathrm{ml}$ \\
Reference toxicant & 0 \\
Toxicological observations & Fenol \\
Toxicological parameters & Luminescence inhibition \\
\hline
\end{tabular}

\section{References}

ISO 11348-3 (2007) International Standard. Water quality - Determination of the inhibitory effect of water samples on the light emission of Vibrio fischeri (Luminescent bacteria test) 


\subsection{Freshwater algal growth inhibition test with Raphidocelis subcapitata}

This document summarises WMR SOP E_4_052 (in Dutch): 'Zoetwater algengroeiremmingstest'. The procedure is based upon international guidelines ISO 8692:2016 and OECD 201 (2006).

\section{Description}

The algal species used is the green algae Raphidocelis subcapitata (syn. Selenastrum capricornutum Pseudokirchneriella subcapitata). The standard test procedure has been adapted by reducing the test volume to 96-well plate levels based on Blaise \& Vasseur (2005), Peterson et al. (2005) and SCA (2009). Each concentration is replicated eight times and every well contains a total of $0.25 \mathrm{ml}$ in volume. Each test concentration is inoculated with algae from a log-phase growing culture. The start concentration is approx. 10,000 cells/ml, determined microscopically. The 96 -well plate is incubated under continuous light at $20 \pm 2{ }^{\circ} \mathrm{C}$ and shaken. For each test concentration, a number of wells is not inoculated with algae, in order to allow for correction for context values and water color. Growth is measured as change in fluorescence reading relative to the start. At the start and the end of the test fluorescent readings are validated with microscopic cell counts. Measurements are taken after $24 \mathrm{~h}$, $48 \mathrm{~h}$ and $72 \mathrm{~h}$. A difference in growth (between the sample and the control) is attributed to the effect of the sample on the organisms.

\section{Quality assurance}

- At start and end of the test the fluorescent readings are validated with microscopic cell counts.

- The density of the algae in the control group should increase by a factor of at least 16 within the 72-h test period.

- The mean coefficient of variation for section-by-section specific growth rates (days 0-1, 1-2 and 2-3, for 72-hour tests) must not exceed 35\%.

- The coefficient of variation of average specific growth rates in the replicates during the whole test period must not exceed $5 \%$.

- The quality of the algal batch is stipulated by exposing the algae to a substance of which the toxicity is known (potassium dichromate; $\mathrm{K}_{2} \mathrm{Cr}_{2} \mathrm{O}_{7}$ ). The results are compared with the results from previous reference tests with the same species at the WMR laboratory.

Characteristics
\begin{tabular}{|ll|}
\hline Test organism & Raphidocelis subcapitata \\
& $($ exponential growing culture) \\
Salinity range & $0-5 \%$ o \\
Test duration & 72 hours \\
Test volume & $0.25 \mathrm{ml}$ \\
Number of replicates & 8 \\
Test chamber & 96 polystyrene multiwell plate \\
Temperature & $23 \pm 2^{\circ} \mathrm{C}$ \\
Standard test water & Algal medium ISO \\
Method & Fluorescence readings \\
Photoperiod & Culture and test: Permanent illumination \\
Test protocol(s) & ISO 8692 and OECD 201 \\
& (adapted for small volume) \\
Reference toxicant & Potassium dichromate \\
Control growth & Factor 67 \\
& $\mu_{\mathrm{c}}>1.4 \mathrm{r}^{-1}$ \\
Toxicological observations & Inhibition of growth \\
Toxicological parameters & NOEC, $\mathrm{E}_{\mathrm{r}} \mathrm{C}_{10}, \mathrm{E}_{\mathrm{r}} \mathrm{C}_{25}, \mathrm{E}_{\mathrm{r}} \mathrm{C}_{50}$ \\
\hline
\end{tabular}




\section{References}

Blaise C. \& P. Vasseur (2005): Algal microplate toxicity test. In: C. Blaise \& J.-F. Férard (eds.), Smallscale Freshwater Toxicity Investigations. Vol. 1. pp. 137-179.

ISO (2016): International Standard. Water quality - Freshwater algal growth inhibition test with unicellular green algae. ISO 8692:2016(E).

OECD (2006): OECD Guideline for testing of Chemicals. Freshwater Alga and Cyanobacteria, Growth Inhibition Test. OECD Test Guideline 201.

Peterson H.G., N. Nyholm \& N. Ruecker (2005): Algal microplate toxicity test suitable for heavy metals. In: C. Blaise \& J.-F. Férard (eds.), Small-scale Freshwater Toxicity Investigations. Vol. 1. pp. 243-270.

SCA (2008): The direct toxicity assessment of aqueous environmental samples using the Pseudokirchnereilla subcapitata freshwater algal growth inhibition test. Methods for the Examination of Waters and Associated Materials. Standing Committee of Analysts. Environment Agency (National Laboratory Service). Rothley Leicestershire, UK.

\subsection{Freshwater acute immobility test with the crustacean Daphnia magna}

This is a summary of the WMR SOP E_4_054 (in Dutch): 'Daphnia magna immobiliteitstest'. This procedure follows the guidelines MicroBioTests, Inc. that is based upon ISO-NEN 6341.

\section{Description}

For the acute test with the water flea Daphnia magna, the DAPHTOXKIT F (MicroBioTests, Inc.) is used. Ephippia (winter resting-eggs) are hatched in artificial freshwater, 3 days prior to testing. Each concentration is tested using four $4 \mathrm{ml}$ replicates with 5 test organisms each, using rinsing wells to avoid dilution of the test concentrations. Juvenile Daphnids ( $<24 \mathrm{~h}$ old) are exposed to the test concentrations for $48 \mathrm{~h}$. After $24 \mathrm{~h}$ and $48 \mathrm{~h}$ the (im)mobility of the organisms is assessed, as an indication for the viability of the test organisms. Daphnids are considered immobile if they are not able to swim after gentle agitation of the liquid in 15 seconds of observation. This is compared with the control exposure.

\section{Quality assurance}

Immobility in the control exposure should be less than $10 \%$.

For each test series, the quality of the batch of the test organisms is determined by exposing organisms to a substance with a known toxicity (potassium dichromate; $\mathrm{K}_{2} \mathrm{Cr}_{2} \mathrm{O}_{7}$ ). The results are compared with specifications of the test organism batch as provided by the supplier and results from previous reference tests with the same species at the WMR laboratory.

Characteristics
\begin{tabular}{|ll|}
\hline Acute crustacean immobility test & WMR-SOP E_4_054 \\
Int. protocol & ISO-NEN 6341 \\
Test organism & Daphnia magna (<24 h old) \\
Salinity range & $0-3 \%$ o \\
Test duration & $24-48$ hours \\
Test volume & $4 \mathrm{ml}$ \\
Number of organisms/replicate & 5 \\
Number of replicates & 4 \\
Temperature & $20 \pm 2^{\circ} \mathrm{C}$ \\
Standard test water & SFW (ISO standard freshwater) \\
Photoperiod & Hatching: permanent light, $>6000$ lux \\
& Test: Permanent dark \\
Reference toxicant & Potassium dichromate \\
Toxicological observations & Immobility \\
Toxicological parameters & NOEC, EC 25, EC $_{50}$ \\
\hline
\end{tabular}




\section{References}

ISO-NEN 6341 (2012): International Standard. Water quality - Determination of the inhibition of the mobility of Daphnia magna Straus (Cladocera, Crustacea) - Acute toxicity test.

MicroBioTests (s.a.): DAPHTOXKIT F MAGNA. Crustacean toxicity screening test for freshwater. MicroBioTests Inc. Belgium. Standard Operating Procedure V031100.

\subsection{Freshwater acute mortality test with the rotifer Brachionus calyciflorus}

This document summarises WMR SOP E_4_174 (in Dutch): 'Mortaliteitstest met Brachionus calyciflorus'. This procedure follows the guidelines of MicroBioTests, Inc. that are based upon international guideline ISO 19827 (2016).

\section{Description}

For the acute freshwater rotifer test with Brachionus calyciflorus, the ROTOXKIT F (MicroBioTests, Inc.) is used. Dried cysts are incubated in standard freshwater 16-18 h prior to the start of the tests at $25^{\circ} \mathrm{C}$ with continuous illumination. The test is performed in a multiwell testplate using six $0.3 \mathrm{ml}$ replicates with 5 test organisms each, using rinsing wells to avoid dilution of the test water.

The well plate is incubated at $25^{\circ} \mathrm{C}$ in the dark. After 24 hours living and dead larvae in the test wells are counted. Rotifers are considered dead if they do not exhibit any internal or external movement in 5 seconds of observation.

\section{Quality assurance}

- Mortality in the control exposure should be less than $10 \%$.

- For each test series, the quality of the batch of the test organisms is determined by exposing organisms to a substance with a known toxicity (potassium dichromate; $\mathrm{K}_{2} \mathrm{Cr}_{2} \mathrm{O}_{7}$ ). The results are compared with results from previous reference tests with the same species at the WMR laboratory.

Characteristics
\begin{tabular}{|ll|}
\hline Acute rotifer mortality test & WMR SOP E_4_174 \\
Int. protocol & ISO $19827(2016)$ \\
Test organism & Brachionus calyciflorus \\
& $(28-30$ hours after hatching starts) \\
Salinity range & $\%$ \\
Test duration & 24 hours \\
Test volume & $0.3 \mathrm{ml}$ \\
Number of organisms/replicate & 5 \\
Number of replicates & 6 \\
Temperature & $25 \pm 2^{\circ} \mathrm{C}$ \\
Standard test water & SFW (Standard Fresh Water; EPA) \\
Photoperiod & Hatching: permanent light, $>6000$ lux \\
& Test: permanent dark \\
Reference toxicant & Potassium dichromate \\
Toxicological observations & Mortality \\
Toxicological parameters & LC 25, LC 50, NOEC \\
\hline
\end{tabular}

\section{References}

ISO (2016): Determination of the acute toxicity to the freshwater rotifer Brachionus calyciflorus. ISO 19827: 2016.

MicroBioTests (s.a.): ROTOXKIT $\mathrm{F}^{\mathrm{TM}}$. Rotifer toxicity screening test for freshwater. MicroBioTests Inc. Belgium. Standard Operating Procedure V071090. 
Wageningen Marine Research

$\mathrm{T}+31(0) 317480900$

E: marine-research@wur.nl

www.wur.eu/marine-research

Visitors' address

- Ankerpark 271781 AG Den Helder

- Korringaweg 7, 4401 NT Yerseke

- Haringkade 1, 1976 CP IJmuiden
With knowledge, independent scientific research and advice, Wageningen Marine Research substantially contributes to more sustainable and more careful management, use and protection of natural riches in marine, coastal and freshwater areas.

Wageningen Marine Research is part of Wageningen University \& Research. Wageningen University \& Research is the collaboration between Wageningen University and the Wageningen Research Foundation and its mission is: 'To explore the potential for improving the quality of life' 